\title{
FINANCING URBAN FUNCTIONS AND SERVICES
}

\author{
David Davies*
}

\section{INTRODUCTION}

Even the casual student of urban affairs must be impressed by the fact that hardly a day passes without his being subjected to some solemn pronouncement indicating that the vigor, indeed even survival, of our economy is in grave danger if something is not done about the urban crisis. There is no urban crisis today. There are serious problems, but most metropolitan areas will continue to thrive and grow for the foreseeable future. As Raymond Vernon has noted, "To most Americans, the personal experience of urban living seems not one of personal retrogression but of continuous improvement."1

Most important changes within a complex social structure cause stresses and strains in the political, social, and economic fabric of a society. The relatively rapid metamorphosis from agrarian to urban living in the United States is no exception. Associated with this revolution in living habits are new problems in our metropolitan areas. It is, however, important to remember that not all problems should be solved. If the sacrifices (costs) of solving a problem are more than the solution is worth, rational thinking would indicate that no action should be taken to attack the challenge. Affluence-mongers to the contrary, we need to be reminded that we do not yet live in the Afluent Society where time and resources are abundant.

It is also important to identify those problems which are indigenous to urban areas. We are not here primarily interested in the broad problems of culture and society, but rather those challenges which are uniquely associated with city size, population density, and the complex of work and living facilities and patterns within the urban area. ${ }^{2}$

Professor J. W. Milliman has delineated three key economic variables which generate substantial costs as well as benefits, and which need to be carefully considered to insure an efficient urban area. These variables are: ( $\mathrm{r}$ ) land use planning and land market operation; (2) urban transport systems; and (3) social overhead capital facilities (e.g., water, sewage, schools, public utilities, and so on). ${ }^{3}$

The plan of this paper is to concentrate on variables two and three and take up in turn the theoretical problems associated with providing social overhead facilities

- A.B. 1949, Stanford University; M.A. 1952, Ph.D. I955, University of California, Los Angeles. Associate Professor of Economics, Duke University.

The author wishes to express his appreciation to Professor De Alessi and Mr. Borcherding of Duke University for their helpful discussions.

${ }^{2}$ Raymond Vernon, The Myth and Reality of Our URban Problems 30-31 (1962).

${ }^{3}$ See Milliman, Urban Crisis-A Question of Focus (Indiana University Institute of Applied Urban Economics, unpublished memorandum, p. 5 , n.d.).

${ }^{3}$ lbid. 
in an urban area, and the presentation of some of the empirical evidence on (I) the suburban-urban exploitation hypothesis, (2) the infra-urban industry problem, and (3) the patterns in local governmental revenues and expenditures.

\section{Theoretical Problems}

In attempting to isolate the inherent problems of government financing at the urban level, it is useful to identify the major fiscal functions of a democratic government. There are, of course, a large number of distinct although mutually interdependent functions which require particular solutions. Professor Musgrave has categorized for analytical purposes the multiplicity of public economic functions into (r) the stabilization of income function, (2) the redistribution function, and (3) the allocation of resources function. ${ }^{4}$

The objective of policymakers in the stabilization branch of government is to pursue and implement programs which will provide us with a continuing high level of resource utilization (including labor) while avoiding both deflation and inflation. Of those individuals who believe that income stabilization is a proper function of government there is widespread agreement that this function should be the responsibility of the central government. ${ }^{5}$

Professor Brazer has correctly suggested the near impossibility of achieving stabilization through state and local fiscal policy. Income stabilization policies pursued by governments which have stringent debt limits, but do not have the power to change the money supply, impose drastic constraints on a program designed to mitigate violent fluctuations in income. ${ }^{b}$ We do not mean to suggest that there are not ways that local governments can assist the central fisc. There are important mutual interdependencies between central and local governments with respect to stabilization policy. The prime responsibility for the income stabilization function, however, must rest with the central government.

The redistribution function of government in Musgrave's multiple theory of the budget is fulfilled strictly through the use of taxes and transfer payments at the central level of government." Presumably the "proper" distribution, or more pre-

\footnotetext{
- Richard Musgrave, The Theory of Public Finance 5 (1959).

The policy question of whether to stabilize or not is not an economic question, although the economist qua economist can point out the cconomic consequences of such a policy. Ultimately the stabilization issue has to be decided at the ballot box. Americans apparently have decided in favor of governmental income stabilization policies, for the Employment Act of 1946 charges the central government with the responsibility of maintaining high levels of employment, production, and purchasing power. Moreover, for the first time in our history the 1964 presidential candidates of both political parties renounced the principle of an annually balanced federal budget.

.. 'Harvey Brazer, Some Fiscal Implications of Metropolitanism 62 (1962).

${ }^{7}$ For qualifications of this method, see Heller, Economics and the Applied Theory of Public Expenditures, Staff of Subcomm. on Fiscal Polict of the Joint Economic Comm., 85th Cono., ist Sess., Federal Expenditure Policy for Economic Groptit and Staeility (Papers Submitted dy Panelists Appearing Before the Subcomm. on Fiscal Policy) 98-io7 (Comm. Print I957) [hereinafter cited as Federat Expendrture Policy for Economic Growth and Stability].
} 
cisely the magnitude and structure of appropriate target variables, would be provided to the distribution branch through the political decision-making process.

There are in fact, though, many redistributional aspects of governmental finances in the urban area. For example, financing educational services involves in varying combinations the redistribution of income from the rich to the poor, small families to large families, older generations to younger generations, childless adults to parents, and from certain religious groups to other religious and nonreligious groups. ${ }^{8}$ Urban redistribution problems are alleged to be one of the causes behind the very pluralistic local governmental structure. Residents of rich suburban enclaves do not want their incomes redistributed. Consequently they resist absorption attempts on the part of annexation-minded central core cities and other less wealthy local governments.

Since, however, there are over go,ooo local governments, it seems likely that the total impact of each governmental unit acting independently on redistributional policy would lead to total failure in reflecting currently accepted redistributional standards of the nation's individuals. Despite local governmental aberrations from a national policy of income redistribution, the main burden of altering the free market's distribution of income (if income is to be redistributed) must rest with the central government. In any case, and despite the obvious interdependent relationships observed in the real world, we are for analytical purposes excluding urban area governments from conscious roles in performing stabilization and redistribution functions.

On the assumptions, then, that the central government redistributes income "correctly" and stabilizes national income at a constant price level, the main economic objective of local government is its historically accepted goal of providing collective and quasi-collective goods and services. The allocation of resources function is paramount for governments in the urban setting.

To analyze the difficulties in financing and allocating resources it is useful to note briefly the process of exchange in the private market place. In this sector of the economy trading depends among other things on the fact that individuals control and own titles or property rights to the goods or services subject to exchange. If an individual wishes to purchase a good or service, he voluntarily pays the asking price to obtain the property rights to the commodity. In doing so, he reveals his true preferences for economic goods. Each individual by voting with his dollars sends signals to entrepreneurs who translate these signals into varying patterns of production designed to meet the demands of consumers. A buyer, then, is excluded from enjoying the services of a good only if he is unwilling or unable to pay the quoted price for the item. This idea is called the "exclusion principle."

\footnotetext{
${ }^{8}$ Hirsch, Urban Government Services and Their Financing, in WERNER Z. HIRSCH (Ed.), URBAN LIFE AND FORM I42 ( $I_{96}$ ).

${ }^{\circ}$ Musgrave, op. cit. supra note 4 , at 9 .
} 
Collective goods and services are by their nature different from private goods. Professor Samuelson has defined a collective or public good as an economic good in which an individual's consumption of the good does not decrease another person's consumption of that good. ${ }^{10}$ Warren Robinson has expressed this idea of the joint consumption of collective services when he notes that when such a service is supplied to one consumer it must "inescapably be supplied to all consumers, and, being supplied to one consumer, can be supplied to other consumers at zero marginal cost."11 This idea of joint consumption, however, is only a necessary and not a sufficient condition for a collective good or service. The services of a symphony orchestra, for example, will be consumed jointly, but admission prices are charged and the service is normally provided in the market. Unlike the private market, no individual can be excluded from enjoying the services flowing from a public or collective good. The exclusion principle is inoperative.

What are the implications of defining a collective good as one which involves ( 1 ) joint consumption and (2) an inoperative exclusion principle? First, since the services will be consumed in equal amounts by all the people and there is no way to exclude individuals from enjoying the benefits flowing from the good or service, people will offer little, if anything, in the way of voluntary payments. Each individual correctly reasons that the amount of the service he would receive will be unrelated to his payment. The voluntary market mechanism, will, as a result, fail to allocate the optimum configuration of resources to the production of a collective or public good.

If the total cost of the public good under question is relatively small, it is conceivable that the sum of all individual voluntary payments could be in excess of the total monetary value of the goods actually demanded by consumers. In such a situation too many resources would be used to produce the collective good at the cost of giving up too many noncollective goods. The opposite case seems more likely. For a costly program such as our defense establishment, voluntary contributions would almost assuredly total much less than the $\$ 5^{\circ}$ billion or so we spend each year on defense.

Faced with this dilemma over collective goods, individuals will normally subject their neighbors and themselves voluntarily to a certain amount of compulsion through the mechanism of a government. Substituting the governmental budget process for the market mechanism does not, however, eliminate an inherent difficulty surrounding collective goods-i.e., prying true preferences from consumers. The challenge, then, is to devise and select a political decision-making process that will reflect as nearly as possible the true preferences of individuals.

There is a second serious problem associated with collective goods. In two slightly different models, both Samuelson and Musgrave have demonstrated that

${ }^{10}$ Samuelson, The Pure Theory of Public Expenditures, 36 Rev. Econ. Statistics 387 (1954).

${ }^{11}$ Robinson, Benefits Received Financing in the Federal System, 27 Nat. TAx J. 242 (1964). 
there can be no unique Paretian optimum for an economy with collective goods or services. $^{12}$ This conclusion holds even if consumer preferences for public goods were revealed and known. The significance of the Samuelson-Musgrave proposition is that there are an infinite number of Paretian optimums to choose, but we have no criteria upon which to adjudge the one best position.

There are, then, at least two important problems associated with providing collective goods and services. First, the market mechanism breaks down and fails to reveal consumer preferences, and therefore cannot yield an efficient allocation of resources. Substituting a compulsory governmental mechanism for the market does not solve the problem. Voting processes reveal individual preferences imperfectly and only in the very vaguest of outlines. Questions concerning the nature, composition, and magnitude of expenditures and the type and magnitude of taxes are left largely unresolved. Tax and expenditure decisions on various alternatives are settled by policymakers' hunches, intuition, and desires along with a mysteriously obtained reading of the electorate's demands.

As previously noted, a second important problem with collective goods is that, even if preferences were known, there is no unique Paretian optimum when goods and services are consumed in equal amounts by individuals. At this stage of development we have nothing to offer at the national level and little to offer at the local level of government with respect to a resolution of this Paretian problem.

Both the unrevealed preference problem and the Paretian optimum problem are to a degree relevant for urban governments. In an admittedly arbitrary division of governmental services, $\mathrm{O}$. $\mathrm{H}$. Brownlee has classified the following as local collective services: welfare, hospitals, police, fire, and general control. General control includes the activities of the governing (legislative) body, courts, office of the chief executive, central staff services, and agencies concerned with personnel administration, law, recording, and planning and zoning. ${ }^{13}$ The critical reader may wish to exclude hospitals, fire, and police from the classification on the grounds that fees could be charged for these services. Nevertheless, collective goods and services at the local level are not insignificant.

Up to this point we have implicitly carried on our analysis as if there were only two polar positions with respect to classifying economic goods and servicesi.e., public and private. This was the approximately theoretical state of affairs between the time of those two towering economic works by Adam Smith and Alfred Marshall.

For analytical purposes Smith employed a methodological device which we shall call the independence hypothesis. ${ }^{14}$ He used this device to exclude from his theory

${ }^{21}$ Samuelson, supra note Io; Samuelson, Diagrammatic Exposition of a Theory of Public Expenditures, 37 Rev. Econ. Statistic 350-56 (I955); Musgrave, op. cit. supra note 4, at 8r-84.

${ }^{13}$ U.S. Bureav of Census, IV Census of Governments I962, at 612 (r964); Brownlee, User Prices vs. Taxes, in Nationat Bureau of Economic Research, Public Finances: Needs, Sources and Utilization 424 (Buchanan ed, I96I) [hereinafter cited as Public Finances].

is See Milton Z. Kafoglis, Welfare Economics and Subsidy Programs 9 (I96I). 
the indirect effect on individuals or firms as a result of economic decisions made by a different individual or firm. As as result, Smith was able to conclude that each individual, by pursuing his own best economic interests would be "led by an invisible hand to promote an end which was no part of his intention."15 Thus with competition and the independence hypothesis, the market mechanism provides for both the maximization of private and social welfare. In the jargon of the economist, there will be an efficient allocation of resources in accordance with individuals' demands if for each of all goods price equals marginal cost, and the total cost of producing the optimal amount of each good is at a minimum. ${ }^{16}$

Marshall drove the first significant wedge into the classical economic conclusion that the maximization of an individual's private welfare leads to a maximization of social welfare when he introduced the concept of external economies in production. ${ }^{17}$ In certain circumstances he noted that a firm's costs of production were in fact related to the size of the industry. The impact of an action involving an outlay of costs by one firm in an industry could involve economies for other intraindustry firms; yet there is no mechanism whereby the benefiting firms could be charged.

The significance of Marshall's idea is that the independence hypothesis is not universally applicable and that, where it is inapplicable, equating price with marginal cost would not give the optimum allocation of resources. The marginal social cost would be below the marginal private cost and the schism between the two cost concepts would be translated into too few resources flowing into an industry characterized by external economies.

More recently the concept of externalities ${ }^{18}$ has been extended from the production sector to the consumption sector of the economy. There are, it is argued, many goods and services which provide utility not only to the owner, but, in some degree, to other individuals as well. Indeed, Baumol asserts that cases of consumption externalities are the rule rather than the exception. ${ }^{19}$

In order to provide a general rule for discussion, we shall define positive externalities as uncompensated services rendered by an individual and/or association of individuals to another individual and/or association of individuals. Negative externalities are disservices rendered by an individual and/or association of individuals to another individual and/or association of individuals who are not compensated for bearing the disservice. ${ }^{20}$

${ }^{25}$ Adam Smith, The Wealth of Nations 423 (Modern Library, 1937).

${ }^{18}$ See Kafoglis, op. cit. stipra note 14 , at 6 .

17 Alfred Marshall, Principles of Economics 266-90 (1950). See also Viner, Cost Curves and Staply Curves, in Richard V. Clemence (Ed.), Readings in Economic Analysis 23-25 (I950).

${ }^{18}$ Externalities are sometimes referred to as neighborhood or spillover effects.

${ }^{10}$ W. J. Baumor, Welfare Economics and the Theory of the State 166 (I952). This was one of the arguments presented by Veblen in his The Theory of the Leisure Class, but the significance of the point was ignored for some time by some of the more "rigorous" economists.

${ }^{30}$ See Scitovsky, Two Types of External Economies, 62 J. PoLIT. Economy I43-5I (1954); KApocLis, op. cit. supra note 14 , at 12 . 
These definitions permit us to array the collection of all economic goods, services, and disservices on a spectrum. Toward the extreme left-hand portion of the spectrum we could place such disservices as fraud, blackmail, and stealing. In many societies these predatory acts are judged to have extreme negative externalities and are completely outlawed by governments. Further to the right on the spectrum, we might find the disservices of smog and other industrial wastes. Close to but still to the left of center would be a neighbor's unkempt yard. The center of the spectrum would include all those goods and services which meet the prerequisites of the independence hypothesis. Moving from the center out to the right of the spectrum we might find a friend's happy disposition, a neighbor's beautiful flower garden, the existence of outstanding health and hospital services in the community, and education.

We could not expect to find unanimous agreement on which side of the spectrum a service should be placed, or how far out on either side the service should be. The burglar will have different placements and rankings than the law-abiding citizen. An extremely competitive individual who plays the crab grass game might get pleasure out of his neighbor's unkempt lawn. The individuals of any society, however, develop a rough consensus about the placement of most services on the spectrum.

From general observation it appears that a great deal of economic activity involves either positive or negative externalities. Disservices or services of much of this activity, however, could be placed close to the center of the spectrum. Here the degree of misallocation of resources is so small and the cost of adjustment so large that we ignore externalities. As we move further out to the right or left, some individual or voluntary associational arrangements for compensation could be used, although in America our mores seem to dictate against individual arrangements. Faced with a noisy neighborhood party, for example, the average disturbed American acts as if his only alternative is either to call the police or grin and bear it. There may well be, however, a price that the raucous group would be willing to pay in order to buy the disturbed individual's acquiescence, or vice-versa, depending on the status of the legal property rights in noise. ${ }^{21}$

There is a large gray area on each side of our spectrum where there are varying opinions concerning the magnitude and importance of externalities. ${ }^{22}$ Because of ignorance or lack of institutional arrangements, or the high cost of privately resolving conflict, some citizens will turn to government for solutions. Indeed, the great debate between visceral liberals and gut conservatives over the proper level and

\footnotetext{
${ }^{21}$ For an excellent analysis of various alternative solutions to such problems as this one, see Coase, The Problem of Social Costs, 3 J. Law and Economics I (1960).

${ }^{22}$ One of the great challenges to the student of government finance is to quantify externalities in the gray area. For a somewhat optimistic view of the current attack on this problem, see Ackoff, Toward Quantitative Evaluation of Urban Services, in Howard G. Schaller (Ed.), PUblic Expenditure Decisions IN THE URBAN CoMmUNITY 9 I-II7 (I963).
} 
composition of governmental spending centers on the gray areas of our spectrum. Unfortunately, there is a paucity of solid empirical evidence on externalities, costs, and benefits concerning health, air and water pollution, urban renewal, recreational facilities, education, and other topics belabored in the great debate.

We shall call these gray area services quasi-collective or quasi-public goods or services. If the optimal allocation of resources and neutrality in the distribution of income is to be achieved by metropolitan area governments, these quasi-public goods and services must be paid for by those who receive the benefits. ${ }^{23}$ Getting beneficiaries to pay for quasi-collective goods is an extremely complicated problem which the local government decision-maker must face even if his jurisdiction is largely isolated from other local governmental units.

A set of fees charged to the direct beneficiary will not per se get at the indirect beneficiaries. Given that indirect beneficiaries' preferences are unknown to governmental officials, no tax or price would be successful in capturing the proper mix of purchasing power from the various individuals in the community.

Another factor that can complicate achieving an efficient allocation of resources in metropolitan area governments is our political and fiscal system of constitutional federalism. Under this arrangement, intergovernmental relations run the traditional gamut of national-state and state-local relationships in addition to the increasing importance of the emerging national-local level arrangement. There are not only various combinations of vertical relations between different levels of government, but also horizontal relations between and among peer governments within a given level of government.

Horizontal relations between local governments involve opportunities for both cooperation and conflict. Associations such as leagues of cities and municipalities not only act as lobbies on and against the power of other levels of government, but can also serve as a focal point for the resolution of intercity and intraurban conflict. Their uniform model tax ordinances, for example, frequently lower the cost of compliance to multiple-city multiple-outlet businesses. These voluntary associations, however, have not been successful in resolving some of the basic conflicts between and among local jurisdictions.

In an urban area where there may be over rooo separate local goverments, ${ }^{24}$ the analyst is concerned not only with the relationship among individuals and a local government, but also with the relationships among individuals and a whole host of governments. In a pluralistic local governmental setting, a jurisdiction will provide public and quasi-public benefits to its own residents, but quite often these benefits will spill over onto the residents of juxtaposed neighboring jurisdictions which escape the cost of providing the services. Moreover, nonresidents may also be the source of negative externalities to a local neighboring city.

\footnotetext{
${ }^{23}$ Brazer, op. cit. supra note 6 , at 64 .

${ }^{24}$ U.S. Bureat of Census, I Census of Governments ig62, at 12 (1964).
} 
In the balkanized urban area the problem of allocating scarce resources efficiently is even more difficult than the extremely complex challenge that faces the local governmental decision-maker in an isolated community. There are interjurisdictional as well as intrajurisdictional positive and negative externalities when there are multiple contiguous local governmental units. Yet in order to achieve an efficient allocation of resources among competing ends, marginal costs must be equated with marginal benefits for each individual.

Making operational the principle of equating costs and benefits at the margin can be frustrated in an urban environment because of legal restrictions on voting rights between and among jurisdictions. These restrictions exclude nonresidents from the decision-making process in relevant neighboring communities. Moreover, there is the issue of establishing the legality of various property rights. Do, for example, the owners of a factory located on the edge of Community A, which is adjacent to Community $B$, have a legal property right to the unlimited use of the air? If they do, then the smoke that belches forth from the stacks of the factory is a consequence which the residents of Community $B$ have to live with or bargain over. The cost of bargaining and buying clean air rests largely on the residents of B. If these costs are higher than the costs associated with obtaining relief from the state legislature (or even the United States Congress, in some cases), then the local problem is escalated to a more central level of government. If even the costs associated with getting a more central level of government to solve the problem are greater than the value of clean air to the residents of Community $B$, then the status quo will prevail.

If, on the other hand, the owners of the factory do not have property rights to the use of air, they must bear the cost of bargaining and rearranging their production function. Sewage and water problems are other examples which involve the establishment of legal property rights. When legal property rights are in the process of change or are not clear, however, arrangements for resolving conflict and pushing costs and benefits to equality are inhibited.

There is also the question of prying true preferences for governmental services from nonresidents in attempting to meet the cost-benefit criterion in a multigovernmental environment. Even if true preferences were known, there is the additional problem of effectively exacting and collecting correct payments from both direct and indirect nonresident beneficiaries.

We should emphasize that the mere existence of externalities does not necessarily imply that action should be taken to collect money from nonpaying beneficiaries. Such action would be economically justifiable only if the cost of obtaining the funds were less than the amount of money appropriated from nonpaying beneficiaries. It is often economically rational to settle for a state of least im- 
perfection. Because of both the nature of collective and quasi-collective goods and services and our present state of knowledge, local governments, whether isolated or part of an urban area, will have to settle for second order efficiency. ${ }^{25}$

\section{II}

\section{A Partial Conceptual Solution to the Urban Financing Problem}

One can view the typical politically fragmented metropolitan area as a competitive arena where many jurisdictions compete for residents and/or where voters adopt that government which best satisfies their preference patterns. The competition, however, is more closely akin to the economist's more recent formulation of monopolistic competition rather than the classical model of competition. Product differentiation, which is a necessary although not sufficient condition for monopolistic competition, is apparently becoming an important characteristic of local governmental collective and quasi-collective goods and services. ${ }^{26}$

Current and prospective urban dwellers can choose alternative mixes of collective and quasi-collective services from an array of local governmental units. Some individuals may opt to live in the high population density core city which is convenient to cultural attractions, variety shopping, and place of work as well as slums, gang wars, noise, and traffic congestion. Other people may choose to live on small plots of lawn in the large suburbs with new schools and new streets, but sporadic police protection and little, if any, public recreational facilities. Alternatively, some richly endowed suburbs offer large wooded lots and excellent police and fire protection as well as septic tanks and open ditches in place of sewage and storm drains. The sparsely populated industrial enclave frequently offers a variety of public services at relatively low cost to its individual residents.

If it is true that we are approaching the Age of Local Public Services, we may expect a greater variety of governmental services, even though public administrators at the local level appear to be less imaginative than their private counterparts. ${ }^{27}$ Moreover, to illustrate the variety of choice in large urban areas, we should note not only the varied choices of governmental services within the metropolitian area, but also the varying quality of services.

In a most provocative paper Professor Tiebout has provided us with a highly imaginative analysis of local finance in an urban environment. He sees the consumervoter-taxpayer choosing from a myriad of alternative governments that jurisdiction which best fits his set of preferences for public services. The greater the variety and number of local governments, the closer an individual can realize his preference

\footnotetext{
${ }^{25}$ See Buchanan, Federal Expenditure and State Functions, in Federal Expenditure Policy for Economic Growth, op. cit. supra note 7, at r74-79.

${ }^{28}$ For a discussion of the point, see Wilbur R. Thompson, A Preface to URban Economics 2r3 (1963).

${ }^{37}$ See id. at 216.
} 
pattern."8 "Moving or failing to move replaces the usual market test of willingness to buy a good and reveals the consumer-voter's demand for public goods."29

The allocation of resources to public goods will then approximate the situations which would exist if public goods had all the characteristics of private goods. There is in Tiebout's model less adapting to the preferences of individuals by local governments than there is local jurisdictions being "adopted by" 30 economizing and utilitymaximizing consumer-voter-taxpayers.

The significance of Tiebout's contribution is that there is at least something close to a conceptual solution to the public goods problem of joint consumption and nonexclusion at the local level. It is useful, however, to delineate the assumptions (hypotheses) he explicitly used in deriving his interesting proposition in order to understand the heavy artillery that has been employed to attack the Tiebout thesis. They are

(I) individual mobility between and among jurisdictions;

(2) knowledge of differences between and among alternative governmental revenue and expenditure patterns;

(3) a relatively wide choice of governmental units;

(4) no restrictions on employment opportunities;

(5) no externalities associated with local public services;

(6) some factor limiting the optimum size of a community; and

(7) communities seeking to reach that optimum size. ${ }^{31}$

We have precious little empirical information about these hypotheses. Certainly there is not in the real world perfect mobility and knowledge, although Tiebout does cite some evidence on a "surprising awareness of differing revenue and expenditure patterns" by consumer-voter-taxpayers. ${ }^{32}$ One could argue on a priori grounds that the existence of zoning laws as well as racial and religious discrimination decreases mobility. Individuals also live, work, shop, and play across jurisdictional boundaries with the result that externalities (to the individual) do exist. But the fact is, we have little quantitative knowledge concerning the magnitude of external benefits and costs.

As is the case with any complex theory, Tiebout's model does not represent a "true" map of the real world in the balkanized urban area. Until there is more empirical information about human behavior in the urban area, we must, on the one hand, refrain from thinking of the Tiebout theory as a mere rationalization of the status quo in the politically fragmented urban area. On the other hand, we should not uncritically accept the theory as a useful predictive device. We are, how-

\footnotetext{
${ }^{28}$ 'Tiebout, $A$ Pure Theory of Local Expenditures, 64 J. PoLIr. Economy $4 x 6$ (1956).

20 Id. at 420 .

so Alchian, Uncertainty, Evolution, and Economic Theory, 57 J. PoLrr. Economy 2Ir-2I (I950).

31 Tiebout, supra note 28 , at $4 \times 9-20$.

${ }^{32} I d$, at 423 .
} 
ever, in Tiebout's debt for having ground out a set of operational hypotheses against which information can be brought to bear.

III

\section{The Suburban-URban Exploitation Hypothesis}

What are the magnitudes of intrametropolitan governmental externalities? This question is sometimes phrased to delineate the schism between the central city and the suburbs. We are learning, however, that suburbs can manifest markedly different spatial, density, population age, commercial, industrial, and other characteristics. They cannot be lumped together and labeled bedroom cities. Because of the paucity of relevant data, easy generalizations concerning the suburban-core city exploitation hypothesis are difficult if not impossible.

In a pioneering work Amos Hawley discovered that per capita public expenditures of central cities rise as the percentage of the total population in the metropolitan area residing in the core city decreases. ${ }^{33}$ Brazer's intensive study of forty large cities confirms Hawley's discovery. ${ }^{34}$ This factor implies higher and higher central city per capita spending as suburban population grows at a rate faster than that of the core city. Margolis has found that "the ratio of per capita central city public payrolls to those of the total SMSA increases as the percentage of the total urban population which resides in the central city decreases."35 $\mathrm{He}$ also discovered that the ratio of total employment to residents in the central city increases as its share of the metropolitan area population decreases. ${ }^{36}$ None of this information, however, denies the hypothesis that there is no exploitation of the central city by suburban residents. All of the findings may be true, but the suburbanite may be contributing the approximate amount (or even more) required by the central city to finance this daytime resident of the core city. The suburbanite's economic activities within the central city presumably are reflected in higher property values, higher sales, and higher incomes.

Brazer has stated that even if the suburban resident does pay for the central city services he receives, he does not bear any of the high governmental costs associated with the increasing concentration of lower-income families within the core city. He argues further that "to the extent that suburban communities, through zoning regulations and discriminatory practices in rentals and real estate transactions contribute directly to the concentration in the central city of sociocconomic groups which impose heavy demands upon local governmental services, they are, in fact, exploiting the central city."37 In the remaining part of this section of the paper, we

\footnotetext{
${ }^{83}$ Hawley, Metropolitan Population and Municipal Government Expenditures in Central Cities, $7 \mathrm{~J}$. Social. Issues I00-08 (195I).

is Harvey E. Brazer, City Expenditures in the United States 54-59 (1959).

${ }^{35}$ Margolis, Metropolitan Finance Problems, in Public Finances, op. cit. supra note 13, at 299, 258.

said.

${ }^{87}$ BRAzER, op. cit. supra note 6 , at 77 .
} 
shall sketch some guidelines which will help lead us to an evaluation of Brazer's position on the exploitation thesis.

Buchanan has demonstrated that it is normally advantageous for a taxpayer to locate in a wealthier rather than poorer jurisdiction. ${ }^{38}$ If a local government does redistribute income, wealthy individuals in a rich city will normally be subjected to a lower rate of taxation than their equally rich counterparts living in a poor municipality. As a result the widely accepted criterion of horizontal equity in taxation is violated. Moreover, when noncentral governments attempt redistribution policies, the movement of resources caused by these fiscal differentials may actually cause our national income to decline. ${ }^{39}$ An individual in a poor community with a factor income of $\$ 10,000$ and a tax bill of $\$ 1,000$ for redistributional purposes would find it advantageous to take a position in a rich jurisdiction where he earns only $\$ 9,500$, but pays a tax of only $\$ 400$ for redistributional purposes. Such "uneconomic" shifts in the allocation of resources are more apt to occur as a result of fiscal differentials between states, but shifts between local governments within a state can also take place.

Even if local governments use a quid pro quo basis (marginal social costs equal marginal social benefit) to determine the pattern of public resource use, it would still be advantageous for an individual to locate in a community with higher average incomes rather than lower average incomes. This proposition stems mainly from the joint consumption characteristics of pure collective goods and services and is illustrated in the accompanying diagrams. In order to concentrate on the income aspects of the problem, we shall assume no interjurisdictional externalities and no differences in tastes between the individuals in the rich and poor communities.

Figure one depicts a poor community populated by $\mathrm{Mr}$. A and Mr. B. The lines $A A$ and $B B$ are their respective demands for collective goods and services. The line SS represents a constant cost supply curve for producing collective goods, and DD is the poor community's aggregate demand for collective goods. It is derived by adding Mr. A's and Mr. B's individual demands vertically, not horizontally as is done for private market aggregate demand. The intersection of DD and SS yields the equilibrium quantity of collective goods-i.e., $\mathrm{OQ}$. $\mathrm{Mr}$. A will pay price $\mathrm{Pa}$, and $\mathrm{Mr} . \mathrm{B}$ a price of $\mathrm{Pb}$ in order to obtain $\mathrm{OQ}$ output of collective services. Unlike the private market, individuals obtain the same output which is collectively shared, but pay different prices.

Figure two is constructed in a way similar to figure one. The reason Mr. X and Mr. Y obtain more collective goods and services than $A$ and $B$ is that they have higher incomes. The dotted line $A_{\mathbf{r}} A_{\mathbf{r}}$ in figure two helps to demonstrate why individuals might move to a richer community. If $\mathrm{Mr}$. A should emigrate from the poor to the rich locality, $\mathrm{BB}$ is now the only relevant aggregate demand for governmental

${ }^{3 a}$ Buchanan, Comment, in Public Finances, op. cit. supra note 13 , at 122-29.

${ }^{30}$ Id. at I29. 
Low Per Capite Income city

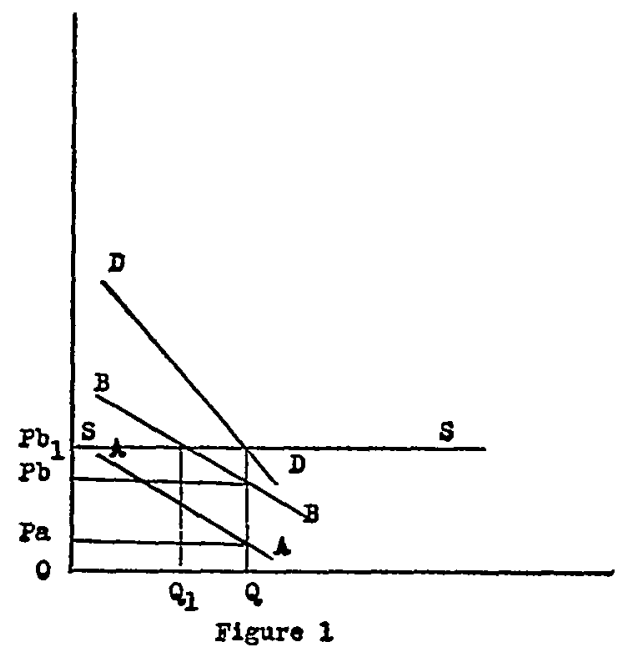

H1gh Por Capita Incoso City

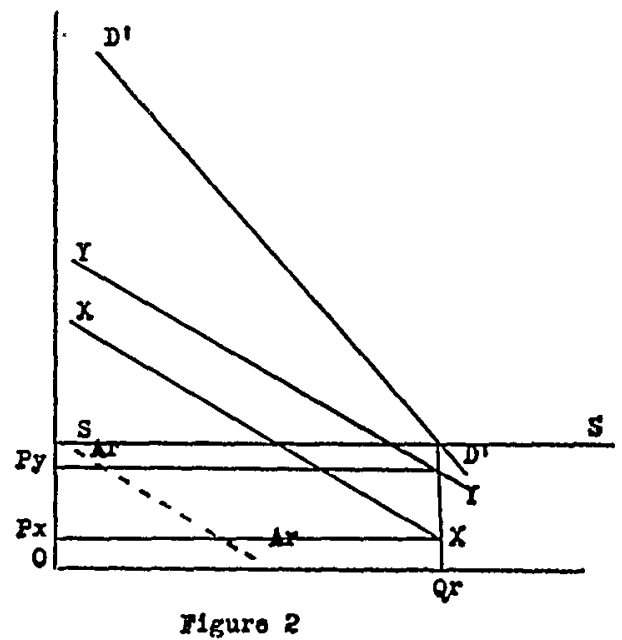

goods and services in the poor city. Accordingly, Mr. B will pay price OP obtain $\mathrm{OQ}_{1}$, quantity of public services. As Mr. A enters the rich community his demand does not alter the aggregate demand for collective goods and services through the relevant range. Because of his relatively low income, his demand or $A_{r} A_{r}$ is such that he pays no price or fee for governmental goods even though he enjoys $\mathrm{OQ}_{\mathrm{r}}$ output of public services along with $\mathrm{Mr}$. X and Mr. $\mathrm{Y}$ who also enjoy $\mathrm{OQ}_{\mathrm{r}}$ output.

Because of fiscal advantages of this type, part or all of the expected extra value inherent in the public sector of the rich community may be capitalized in the price of the land. In an unrestricted free market for property, the original owners stand to make capital gains.

All governmentally provided goods and services in a rich community, however, are not pure collective goods. Some of them are quasi-collective goods and may be financed by some combination of taxes and fees. As new families move into this type of community, relatively less public swimming pool space, swings, and so on, are available to the original rich residents than before the immigration of low per capita income residents. The early settlers of a wealthy community, then, may be willing to exclude low-income families from their neighborhoods by means of various restrictive devices. ${ }^{40}$ In effect, the rich are willing to trade their capital gains in order to preserve their fiscal advantages.

The economic reasoning outlined here is only a partial explanation of the existence of restrictive devices. There are, of course, many other reasons both obvious and subtle.

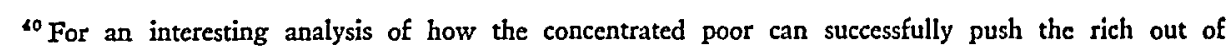
their old neighborhoods in the absence of restrictions, see Margolis, Metropolitan Finance Problems, in Public Finances, op. cit. supta note 13 , at 236-37. 
Existing suburban restrictions do reduce the mobility of certain central city residents. Any change from the status quo-i.e., from existing restrictions, involves gains and losses to different sets of individuals, but the economist qua economist cannot at this stage of development determine whether total welfare in the metropolitan area would increase or decrease if the barriers were removed. Brazer's indictment of suburban restrictions is a position with which many individuals could easily sympathize, but it is a value judgment.

\section{IV}

\section{INframetropolitan Probiems with Industry}

Part of the folklore of urban finance is wrapped in the largely uncritical acceptance of the hypothesis that the attraction of new industry is fiscally advantageous for a local community. In order to keep taxes relatively low, local governmental decisionmakers vie for commercial and industrial enterprises. In some cases urban governments even grant "tax holidays" for new industrial properties, although this practice is not common among large cities. ${ }^{41}$

Mabel Walker has pointed out that much has been written about the effect of varying tax patterns on the location of industry, but very little has been done with the analysis of the impact of the location of industry on tax revenues and tax rates. ${ }^{42}$ The conclusions of the few studies which attack this problem do not agree with respect to the net gains to be realized from attracting industrial activity.

Louis Loewenstein has catalogued various empirical cost-revenue studies on industrial location. ${ }^{43}$ The Frederick P. Clark and Associates reports purport to show that industry provides the local government a ratio of revenue to costs of about three to one in Greenwich, Connecticut, ${ }^{44}$ and four to one in Yorktown, New York. ${ }^{45}$ Homer Hoyt Associates derive a revenue cost ratio of three to one in Evanston, Illinois, ${ }^{46}$ and five to one in Arlington, Virginia. ${ }^{47}$ Two other studies of the Philadelphia and Boston areas also infer that industry produces a ratio of revenue to costs in excess of one. ${ }^{48}$ These results imply that industry pays somewhere between three to five times in taxes more than what they cost the local jurisdictions which provide the various governmental goods and services required by industry.

Empirical cost-revenue studies have not been without their critics. Barnes and Raymond note the importance of the assumptions underlying cost allocation as well

${ }^{\$ 1}$ Feinberg, The Implications of Core City Decline for the Fiscal Structure of the Core-City, I7 NaT. Tax. J. $216(1964)$.

${ }^{43}$ Mabel Walker, Business Enterprise and the City 37 (1957).

${ }^{13}$ Loewenstein, The Impact of New Industry on the Fiscal Reventes and Expenditures of Suburban Communities, i6 Nat. TAX J. II3 (1963).

"Frederick P. Clark and Associates, Economic Study (1954).

"Frederick P. Clark and Associates, Land Use and Community Taxes (i958).

so Homer Hoyt Associates, Economic Survey of the Land Uses for Evanston, Illinois (I948).

"7 Homer Hoyt Associates, Economic Survey of the Land Uses of Arlington County, Virginia (195I).

${ }^{4}$ Loewenstein, supra note 43 , at $115-16$. 
as the statistical limitations of most cost-revenue statistics. ${ }^{40}$ Coughlin and Isard have warned of the importance of investigating secondary cost factors arising as an indirect result of the attraction of new industry ${ }^{50}$ Among other weaknesses of urban area cost-revenue analyses, Wheaton has noted the neglect of future industrial expansion costs to the governing jurisdiction, and the arbitrary weighting of charges or costs to residential areas. ${ }^{51}$ Margolis has also stressed the point that "accompanying the business use of land there will be a change in the nature of residential uses and an expansion of public services so that tax costs per dollar of property value will increase." $" 52$

The more recent studies on the desirability or undesirability of attracting local industry appear to be more promising since they meet some of the previously mentioned criticisms. As a result of his excellent case studies, Louis Loewenstein concludes that suburban municipalities can improve their financial position by attracting new industries and encouraging the growth of existing firms which not only have a relatively high value of assessment per employee, but also have employees who are not likely to relocate as a result of industrial relocation or growth. "Establishments which are semi-automated in nature such as petroleum refineries or radio and transmitting towers" would probably be assets to a municipal fiscal structure. Loewenstein suggests that those types of industries which hire many secondary workers, unskilled, and older female help, such as the garment and needle trades would also appear to be beneficial to a municipality because of the low probability of these workers moving their homesites to their places of work..$^{53}$

In a recent analysis published at the same time as the Loewenstein study, Professors Groves and Riew derive propositions similar to Loewenstein's. In attempting to assess whether industrialization provides a net fiscal gain or loss to a community, Groves and Riew emphasize evaulating the following factors: (I) the capital-labor ratio, (2) the nature of the labor force, (3) the dispersion of the labor force in the urban area, (4) the dependent to employee ratio, and (5) the amount of governmental services directly required by industry. The higher the capital to labor ratio, the higher the skills and wages of the labor force, the lower the dependent to employee ratio and the more laborers with low valued homes and other capital who live outside the jurisdiction, the greater the fiscal advantage (or the less the disadvantage) to the industrializing jurisdiction. ${ }^{54}$

Brazer's study of the city of Detroit supports the hypothesis that a city's acquisition

\footnotetext{
${ }^{10}$ Barnes \& Raymond, The Fiscal Approach to Land Use Planning, 21 J. AM. INST. of PLANNers, 2-3, $7 \mathrm{I}-75$ (I955).

${ }^{\circ 0}$ Robert E. Coughin \& Walter Isard, Municipal Costs and Revenues Resulting mrom ConMUNITY GRowTH 44 (I957), referred to in Loewenstein, stipra note 43, at 115.

${ }^{61}$ Wheaton, Application of Cost-Revenue Studies to Fringe Areas, $30 \mathrm{~J}$. Am. Inst. of PLanners 170-73 (1959).

${ }_{63}$ Margolis, Municipal Fiscal Structure in a Metropolitan Region, 65 J. Poulr. Economx 236 (1957).

${ }^{63}$ Loewenstein, supra note 43 , at 134 .

${ }^{54}$ Groves \& Riew, The Impact of Industry on Local Taxes-A Simple Model, I6 NAT. TAX J. 138-42 (1963).
} 
of new commercial and industrial property tends to reduce effective tax rates. He cautions against broad generalizations, however, and suggests a study of the factors mentioned by Groves, Riew, and Loewenstein before judging whether industrialization is fiscally advantageous in specific cases. ${ }^{55}$

In a thorough theoretical and empirical study of the fiscal impact of industrialization on local schools, Werner Hirsch isolated several revenue and cost variables in an attempt to assess the fiscal effects of industrialization. ${ }^{56}$ The revenue factors include changes in ( $\mathrm{I}$ ) industrial and commercial property values, (2) employment, (3) number of families, (4) residential property values, and (5) public-school enrollment which is the basis for state financial aid to schools. Cost factors also include changes in employment and public school enrollment, for these variables affect both school operating and capital costs. Hirsch discovered after accounting for both direct and indirect revenue factors (except the indirect revenue from state aid) and pertinent cost factors that in thirteen of the sixteen industries he analyzed, industrialization led to net losses in fiscal resources to the jurisdiction. Net gains resulted only from the petroleum-coal, chemicals, and motor vehicles industries. The industry which caused the greatest net loss was textile and apparel manufacturing. ${ }^{57}$

When Hirsch made adjustments for state aid to schools, ten of the sixteen industries proved to be fiscally advantageous to the school district. Textiles and apparel manufacturing, however, still caused the greatest deterioration in the fiscal status of the tax jurisdiction. Hirsch concluded that his study "confirms the claim that industrialization, on the average, improves the fiscal health of a school district, but only if state aid is included as a revenue source." 58

It appears that on the basis of the rather limited but more sophisticated recent analyses that industrialization is not an unmixed blessing to local governments. As discussed by Hirsch and others, relatively low paying industries have many employees with school age children. Thus, while they contribute to increasing costs, such industries and individuals have relatively low assessed valuation of plants and homes. The opposite case, however, apparently holds for highly capital intensive industries. The indiscriminate wooing of industry would seem to be a highly unpromising method to achieve fiscal advantage for local governments.

\section{$\mathrm{V}$}

\section{URBAN EXPENDITURES}

There have been at least two major changes in American living patterns during the past half century. First, we changed from a primarily farm to an urban society. By 1920 just over half our population lived in cities, and an additional nineteen

${ }^{ \pm 0}$ BRAzER, op. cit. supra note 6 , at 70-7I.

${ }^{t 0}$ Hirsch, Fiscal Impact of Industrialization on Local Schools, 46 REv. ECON. AND STATISTICs 193 $(1964)$.

E7 Id. at $195-98$.

cs Ibid. 
per cent of the people were classified as rural nonfarm. In ig6o, only one out of every fourteen Americans were farm dwellers. ${ }^{59}$ The second major change in living patterns is the largely postwar switch to the suburb which together with the old central city has spawned the metropolitan area. Today almost seventy per cent of the population lives in Standard Metropolitan Statistical Areas (SMSAs), ${ }^{00}$ and over half of these individuals live in suburbs. ${ }^{61}$ The number of people living in the 212 SMSAs increased by over twenty-six per cent from $195^{\circ}$ to 1960 , while the rest of the population grew by only seven per cent. ${ }^{62}$ Over eighty per cent of the population growth in the SMSAs during the $195^{\circ}$ decade occurred in the suburbs. ${ }^{03}$ It has been estimated that by 1975 over sixty per cent of the SMSA population will live in suburbs. ${ }^{64}$

There have been major economic changes associated with the dramatic shifts in the American population. By rg6o over seventy-five per cent of all bank deposits in the United States were located in SMSAs. These areas also accounted for approximately seventy-five per cent of all manufacturing payrolls, value added by manufacture, and number of employees. ${ }^{65}$ Since 1950 the largest percentage gains in employment have been in the primarily metropolitan-linked activities of medical care, engineering and business services, public education, and other governmental services. ${ }^{66}$

As might be expected from examining demographic changes, there has been a persistent growth in the number of dwelling units since World War II. At the beginning of the $195^{\circ}$ decade the nation had 46 million dwellings. By 1960 this figure had increased to over $5^{8}$ million or by approximately twenty-seven per cent. These statistics represent net increases, for over 4.5 million units were either torn down or abandoned during the decade. The cost of new dwellings is now at the rate of over $\$ 25$ billion annually or about 4.5 per cent of our Gross National Product. $^{67}$

Most of the dwellings built in the United States since World War II have been single-family houses. The major part of the new housing built during the $195^{\circ}$ decade was constructed in the SMSAs. While over three million units were built in the central cities, almost six million units were constructed outside the central

${ }^{60}$ Arnold B. Barach, U.S.A. ANd Its Economic Future II (1964).

${ }^{\circ 0}$ An SMSA consists of a county or two or more contiguous counties each with one city or two contiguous cities with a population of 50,000 or more. A Standard Metropolitan Statistical Area can be used as rough proxy variable for a metropolitan area. For a more rigorous definition of an SMSA, sce Robert G. Smith, Public Authorities, Special Districts, and Local Government $155-57$ (1964).

${ }^{61}$ Barach, op. cit. supra note 59 , at 96 .

${ }^{02}$ Milliman, supra note 2, at 8 .

${ }^{\text {es }}$ For an excellent analysis of the relationship between rates of growth in population and state-local expenditures, see Spangler, The Effect of Population Growth Upon State and Local Government Expenditures, i6 Nat. Tax J. I93-96 (1963).

${ }^{64}$ Commttree for Economic Development, Guiding Metropolitan Growth i6 (1960).

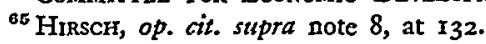

${ }^{a}$ Committee for Economic Development, op. cit. supra note 64 , at 17 .




cities but within the SMSAs. These factors are reflected in our spreading suburban sprawl. In the decade of the ig6os, however, construction of apartment houses has boomed. While in 1955 only one out of ten new dwellings was an apartment, in rg62 one out of three new dwellings was an apartment unit. ${ }^{68}$ This factor would imply further increases in the population density.

Central cities are subject to the pressures of serving a daytime population thirty to fifty per cent larger than the core city residential population. This growth of congestion with all its consequent problems seems only to be encouraged by providing more and more expensive expressways and parking spaces. ${ }^{69}$

Central cities also continue to serve the historic function as the immigration and settling center for low-income migrants who must adapt to their strange new environment. Urban blight which afflicts commerical and industrial areas as well as residential neighborhoods continues to plague the core city. There is also evidence to indicate that blight is a fact in some suburbs. It is interesting to note, however, that in r950 the Census Bureau estimated that approximately ten per cent of our houses were "dilapidated," while in I960 this figure had decreased to five per cent. $^{70}$

In the relatively newer suburbs the demand for new schools, water and sewage systems, fire protection, streets, and utility lines has increased dramatically since the end of World War II. The vast majority of new houses being constructed are built in suburbs, and it has been estimated that each new home in a suburban development is associated with a public capital outlay of between $\$ 2,500$ and $\$ 3,500$, depending on the particular characteristics of the development. Governmental per capita capital outlays are substantially higher in suburbs than either in the core city or rural area. ${ }^{71}$

Metropolitan area-wide problems have also increased as a result of demographic and economic changes. The mass use of motor transportation has contributed to mass congestion. The traditional transportation network of public transportation, rail commuter service, and motor transportation has been thrown out of balance. This imbalance is due partly to the fact that the ownership of these both competing and complementary transport facilities rests in a maze of public agencies and private companies. $^{\mathbf{7 2}}$ The federal government has also aggravated the problem by pouring billions of dollars into the largely exclusive support of automobile and truck transportation, although the Advisory Commission on Intergovernmental Relations has recommended that the central government support metropolitan mass transportation facilities and services. ${ }^{73}$ Other serious metropolitan area-wide problems

${ }^{\mathrm{os}}$ Ibid.

${ }^{\circ}$ Committee for Economic Development, op. cit. supra note 64 , at I9.

${ }^{70}$ BARACH, op. cit. supra note 59 , at $4^{\mathrm{I}-42}$.

${ }^{72}$ Committee for Economic Development, op. cit. supra note 64 , at $2 \mathrm{x}$.

${ }^{72}$ Vernon, The Economics and Finances of the Large Metropolis, 90 DaEdalus 42 (Ig6r).

${ }^{73}$ Advisory Commision on INtergovernmental Relations, Intergovernmental Responsibilities for Mass Transportation Facilities and Services in Metropolitan Areas 12-r3 (1961). 
TABLE I

Per Cent of a State's Local Finances in Its SMSAs, rg62

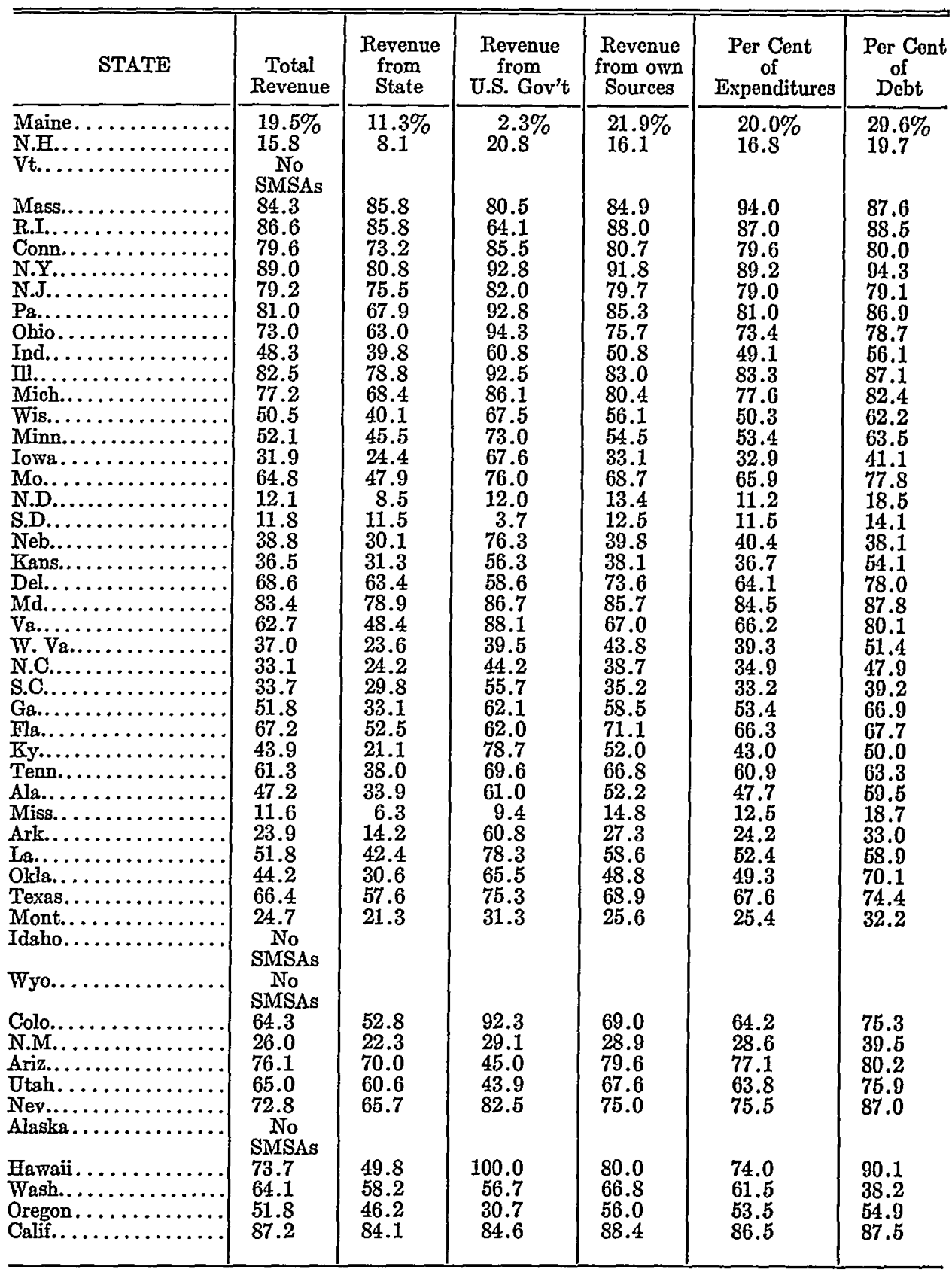

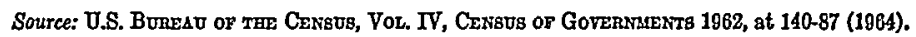


include the pollution of our air and water, policies with respect to fringe-area vacant land which is being absorbed into the metropolitan area at the rate of approximately one million acres a year, and questions relating to the pattern of industrial development. ${ }^{74}$

The challenges and problems briefly outlined above have been responsible for significant increases in local governmental spending. Direct local government expenditures increased from \$9.I billion to $\$ 42.3$ billion or by 365 per cent between 1946 and $1963 .^{75}$ The ratio of local expenditures to net national product increased from 4.7 per cent in 1948 to 7.1 per cent in 1962 . These relationships imply that the income elasticity of local public spending is considerably greater than unity. ${ }^{76}$

Table one shows what per cent of total revenues of local governments in a state was received by governments located in the SMSAs during I962. Similar percentages for the SMSAs are also derived for the following categories: $(x)$ revenue distributed to local government by the state government; (2) revenue distributed to local government by the federal government, (3) revenue derived from own sources, (4) the percentage of total local spending done by governments in SMSAs, and (5) the percentage of total local debt incurred by governments in SMSAs.

As expected, those states with large metropolitan populations have the greatest proportion of local governmental spending in their SMSAs. In twenty-eight states over half of all local governmental expenditures are made in metropolitan areas. ${ }^{77}$ Including Alaska, Idaho, Vermont, and Wyoming, which have no SMSAs, over seventy per cent of all local governmental spending is done by jurisdictions within metropolitan areas. These data suggest the financial importance of urbanized areas.

Table two shows the composition of local governmental expenditures of urban areas for various functions in 1960 and the average percentage annual increase in per capita amounts by function between 1952 and I960. Basic local governmental expenditures averaged approximately $\$ 2 \mathrm{I} 2$ per person. The expenditures for public schools, which averaged about $\$ 88$ per capita, was the largest single item, representing 4I.5 per cent of total urban expenditures and over 343 per cent more on a per capita basis than the category of streets and roads, which was the second most important function.

Per capita local governmental expenditures of urban areas for all functions averaged an annual increase of about 6.7 per cent between 1952 and I960. This average figure of 6.7 per cent was exceeded by the annual per capita growth rates in the functions of public welfare, airports and terminals, public schools, and local parks and recreation. Since on a per capita basis the annual average growth rate in

\footnotetext{
74 Commitree for Economic Development, op. cit. supra note 64, at 23-24.

76 U.S. Bureau of the Census, Historical Statistics of the United States 730 (i960); U.S. Bureau of the Census, Governmental Finances in 1963 , at 30 ( 1964 ).

${ }^{70}$ advisory Commission on Intergovernmental Relations, Tax Overlapping in the United States, $x 9^{6} 4$, at $8\left(x_{964)}\right.$.

${ }_{77}$ The SMSA is used here as a proxy measure for a metropolitan area.
} 
TABLE 2

Composition of Local Expenditures of Urban Areas, 1960

\begin{tabular}{|c|c|c|c|}
\hline Function & $\begin{array}{c}\text { Per Capita } \\
\text { Amount }\end{array}$ & $\begin{array}{c}\text { Per Cent } \\
\text { of } \\
\text { Total }\end{array}$ & $\begin{array}{c}\text { Average Annual } \\
\text { Increase in Por } \\
\text { Capita Amount, 1952-60 }\end{array}$ \\
\hline Public Schools................... & $\$ 87.88$ & $41.5 \%$ & $8.6 \%$ \\
\hline 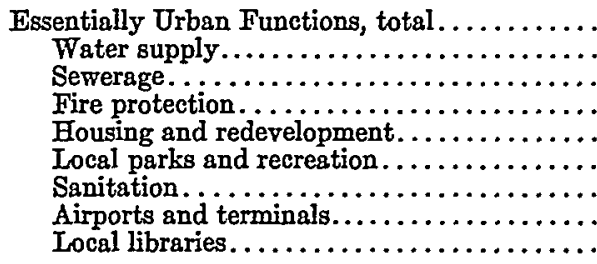 & $\begin{array}{r}59.13 \\
15.21 \\
10.02 \\
8.26 \\
7.80 \\
6.31 \\
5.13 \\
4.28 \\
2.12\end{array}$ & $\begin{array}{r}27.9 \\
7.2 \\
4.7 \\
3.9 \\
3.7 \\
3.0 \\
2.4 \\
2.0 \\
1.0\end{array}$ & $\begin{array}{l}5.2 \\
5.8 \\
5.9 \\
4.1 \\
1.8 \\
8.6 \\
3.0 \\
9.4 \\
6.2\end{array}$ \\
\hline  & $\begin{array}{r}64.96 \\
19.81 \\
11.12 \\
11.05 \\
3.87 \\
1.44 \\
8.46 \\
2.30 \\
6.91\end{array}$ & $\begin{array}{r}30.6 \\
9.3 \\
5.2 \\
5.2 \\
1.8 \\
.7 \\
4.0 \\
1.1 \\
3.3\end{array}$ & $\begin{array}{r}6.0 \\
4.5 \\
5.6 \\
6.3 \\
9.7 \\
6.3 \\
5.6 \\
5.4 \\
10.4\end{array}$ \\
\hline Grand Total. & 211.97 & 100.0 & 6.7 \\
\hline
\end{tabular}

Source: Manvel, Changing Paterns of Local Urban Expenditure, in Howard G. Sczutuen (ED.), Poduc Expendrons Deciorong IN THE URBAN COMAONITT 23 (1963).

urban-generated gross national product was only 2.7 per cent, ${ }^{78}$ the urban income elasticity of each urban expenditure function except housing and redevelopment is in excess of one. In the case of public welfare, every one per cent increase in per capita urban income is associated with a 3.6 per cent increase in per capita local urban spending for this most rapidly growing function.

The probability that local spending will continue to increase at relatively rapid rates is quite high. The estimates included in the relatively recent statistical studies on projected state-local spending have all proved to be on the conservative side. The most recent projections are striking. The National Planning Association estimated state-local spending for I970 at $\$ 94.2$ billion or sixty per cent higher than the Ig60 total. In a report to the President and Congress, the Outdoor Recreation Resources Review Commission forecast total state-local outlays in 1970 of $\$ 97.5$ billion, which is about a sixty-seven per cent increase over the actual total in $1962 .{ }^{70}$

${ }^{78}$ Manvel, Changing Patterns of Local Urban Expenditure, in Howard G. Schatlen (ED.), Punlic Expenditure Decisions in the URban Community 22 ( 1963 ).

${ }^{70}$ Cf. Otto Eckstein, Trends in Public Expenditures in the Next Decade (1959); Netzer, The Outlook for Fiscal Needs and Resources of State and Local Governments, 48 AM. EcoN. Rev. 317-27 (1958); Netzer, Financial Needs and Resources Over the Next Decade: State and Local Governments, in Public Finances, op. cit. stipra note 13 , at 23-65; and Papke, Looking Forward in State and Local Revenues: A Prospective Analysis, in Proceedings of the Seventh National Conference on School Finance 143-50 (Ig64). 
Our recent history indicates that federal spending is leveling off somewhat while local, and especially local urban, spending is increasing rapidly. Excluding drastic changes on the international scene, one student of government has estimated that state-local outlays will exceed total federal budgeted expenditures by I97I. State and local governments already employ 7,500,000 employees compared to only $2,500,000$ federal workers. ${ }^{80}$

The prospects of future urban expenditures seem fairly obvious. Continued economic growth, urbanization, population growth, and price level changes all point to rapid rates of growth in urban outlays. Changing institutional patterns manifested in consumer demands for both quantitative and qualitative changes in such diverse areas as health and hospital care, lower and higher education, sanitation, housing and urban renewal, police and fire protection, transportation (including streets, roads, mass transit, and airports), welfare, and such amenities as parks, recreation facilities, and libraries will be at the root of future rapid increases in metropolitan area governmental spending. ${ }^{81}$

\section{VI}

\section{Urban ReVENUES}

How will urban governments raise the billions of dollars necessary to meet the predicted increase in expenditures over the next decade? There are three main sources of revenue available to the governments in metropolitan areas. After a brief examination of overall patterns in local revenues, we shall take up in order taxes, fees, and grants. ${ }^{82}$

Table three shows the composition of local governmental revenue for 1946 and 1963. Total revenue, excluding utility, liquor store, and insurance trust receipts, has increased by $40 \mathrm{r}$ per cent since the end of World War II. Despite the fact that property taxes increased by 3I0 per cent over the same period of time, this source of revenue decreased from 57.6 in 1946 to $47 . \mathrm{I}$ per cent of total revenue in 1963 . In the decade of the I920s, property taxes accounted for seventy-five per cent of all local revenues.

Federal and state grants in aid have increased from 26.I to 30.8 per cent of total revenue. The sales and income tax category, which is dominated by sales tax collections, has increased by 768 per cent since the war, but still only accounts for 4.5 per cent of total revenue. Fee collections have increased by $5^{88}$ per cent and constitute I5.4 per cent of total revenues. Disregarding changes in rates of taxation and increased fees, the elasticity of revenue with respect to Gross National Product

${ }^{80}$ Anderson, Can the State Live on Crumbs?, Saturday Review, Jan. 9, 1965, p. 3 .

${ }^{81}$ Manvel, op. cit. supra note 78 , at 23-35.

${ }^{82}$ Because of the limitation of space, we shall not discuss governmental borrowing. This is, however, an important area, for state-local debt has increased from 6 to $14 \%$ of gross national product during the postwar era. Between 1946 and 1963 state-local debt has grown by over $11 \%$ per year, a striking rate of growth exceeded only by consumer and mortgage debt. 
TABLE 3

Sources of Local Governmental Revenue, 1946 and 1963 (In millions of dollars)

\begin{tabular}{|c|c|c|c|c|c|}
\hline \multirow[b]{2}{*}{ Sources } & \multicolumn{2}{|c|}{1946} & \multicolumn{3}{|c|}{1963} \\
\hline & Amount & $\begin{array}{c}\text { Per Cent } \\
\text { of } \\
\text { Total }\end{array}$ & Amount & $\begin{array}{c}\text { Per Cent } \\
\text { of } \\
\text { Total }\end{array}$ & $\begin{array}{c}\text { Per Cont } \\
\text { Increaso } \\
1046-1963\end{array}$ \\
\hline 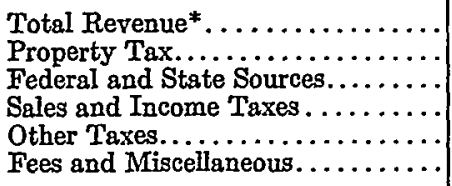 & $\begin{array}{r}\$ 8,227 \\
4,737 \\
2,145 \\
216 \\
204 \\
925\end{array}$ & $\begin{array}{r}100 \% \\
57.6 \\
26.1 \\
2.6 \\
2.5 \\
11.2\end{array}$ & $\begin{array}{r}\$ 41,218 \\
19,401 \\
12,689 \\
1,875 \\
888 \\
6,365\end{array}$ & $\begin{array}{l}100.0 \% \\
47.1 \\
30.8 \\
4.5 \\
2.2 \\
15.4\end{array}$ & $\begin{array}{l}401 \% \\
310 \\
402 \\
768 \\
335 \\
538\end{array}$ \\
\hline
\end{tabular}

*Excludes utility, liquor store, and insurance trust revenues.

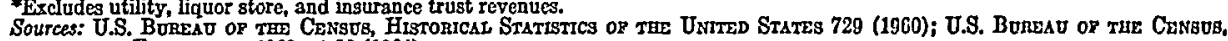
Governasental FrNances in 1963 , at 22 (1964).

is well over one for all categories. The income elasticity coefficients range from I.7 for property taxes to 4.3 for sales and income taxes. The other revenue categories fall within this range.

Turning back to table one, we can see, as expected, that those states with large metropolitan populations have the greatest proportion of total revenue, state aid revenue, federal aid revenue, and revenue from sources in their own SMSAs. In twenty-eight states over half of total local revenue is associated with the metropolitan areas, but in only nineteen states does over half of the state aid to local governments go to jurisdictions in the SMSAs. In thirty-four, thirty-one, and thirty-three states, respectively, over half of total federal aid, total local revenue from own sources, and total local debt are associated with urban governments. Over seventy-four per cent of all federal aid to local governments, 73.4 per cent of all local revenue from own sources, 70.6 per cent of all local expenditures, and 76.6 per cent of all local debt are associated with governments in metropolitan areas. Yet only sixty-one per cent of all state aid to local governments is channeled to the SMSAs. These data are consistent with the hypothesis that there is a rural over-representation in the state legislatures.

It should be noted that federal aid to local governments amounted to only $\$ 685$ million in 1962 while state aid to local governments exceeded \$ro.8 billion. A significant proportion of state funds, however, are received from the central government. Federal grants have increased by over 292 per cent between 1954 and 1965 , and will be fifteen per cent of estimated state and local revenues for $1965 .{ }^{83}$

Although declining in importance as a revenue source, the property tax has been and still is the single most important source of revenue for urban governments. While this source of revenue accounted for only 47.1 per cent of all revenues received

${ }^{83}$ The Growing Echo in the States' Vaults, Business Week, Sept. 19, 1964, p. 112. 
TABLE $_{4}$

Local Governmental Revenue, Distribution by Source, ig62

\begin{tabular}{|c|c|c|c|c|c|c|}
\hline Source & Counties & Municipalities & Townships & $\begin{array}{c}\text { School } \\
\text { Districts }\end{array}$ & $\begin{array}{l}\text { Special } \\
\text { Districts }\end{array}$ & $\begin{array}{l}\text { Total } \\
\text { Local }\end{array}$ \\
\hline $\begin{array}{l}\text { Property tax........... } \\
\text { Other taxes............ } \\
\text { Nontax revenue....... } \\
\text { Intergovernmental..... } \\
\text { Totals............. }\end{array}$ & $\begin{array}{l}45.6 \% \\
3.2 \\
12.4 \\
38.7 \\
100.0\end{array}$ & $\begin{array}{l}44.0 \% \\
16.1 \\
19.5 \\
20.4 \\
100.0\end{array}$ & $\begin{array}{c}63.8 \% \\
4.0 \\
8.4 \\
23.8 \\
100.0\end{array}$ & $\begin{array}{c}51.2 \% \\
.7 \\
7.5 \\
40.6 \\
100.0\end{array}$ & $\begin{array}{c}26.1 \% \\
- \\
53.8 \\
20.1 \\
100.0\end{array}$ & $\begin{array}{l}48.0 \% \\
6.6 \\
14.9 \\
30.5 \\
100.0\end{array}$ \\
\hline
\end{tabular}



by local governments in 1963 , the property tax as a percent of locally collected receipts was sixty-eight per cent. In 1962 the property levy amounted to eighty-seven per cent of local tax revenues. As shown in table four, the property tax is the major producer of local revenue for counties, municipalities, townships, and school districts. Only in special districts, which by their nature rely heavily on fees, is the property tax not the single most important source of receipts.

The large volume of new construction and the rising level of property values and tax rates have contributed to the increased yield of property taxes. Improved administration of the tax has increased the strength of this most important source of local revenue. ${ }^{84}$ Since World War II, state legislatures have taken an active interest in passing legislation designed to improve local property tax programs. Legislation has been implemented by administrative action. Almost all states maintain a state agency which supervises local governmental activity in the property tax field. This activity encompasses equalization, reappraisal, and general information programs. ${ }^{85}$ While a great deal has been accomplished in improving property tax administration during the past two decades, it is clear that much more can be done to improve the strength of the tax. ${ }^{86}$

Another factor which has contributed to the continuing importance of the property levy in local finance is its greater than expected responsiveness to changing levels of aggregate demand, income, and employment. ${ }^{87}$ In a pioneering paper Groves and Kahn derived a long run income elasticity coefficient of .22 for the property tax in Wisconsin. ${ }^{88}$ In a later analysis, Netzer used an elasticity coefficient of $\mathrm{I} .00$ as the basis for state and local revenue projections. ${ }^{89}$ While this

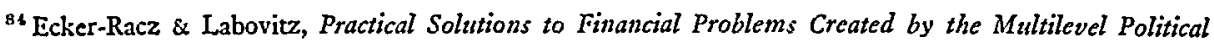
Structure, in Public Finances, op. cit. supra note 13, at 139.

${ }^{85}$ Gronouski, State Stcpervision of Property Tax Administration, yo Nat. TAx J. 158-70 (1957).

so The Advisory Commission on Intergovernmental Relations, The Role of the States in Strengthening the Property Tax, Vols. I, III (I963).

${ }^{87}$ See Alvin H. Hansen \& Harvey S. Perloff, State and Local Finance in the National Economy $57-58$ (1944).

${ }^{83}$ Groves \& Kahn, The Stability of State and Local Tax Yields, 42 AM. Econ. Rev. 90 (1952).

${ }^{80}$ Netzer, Financial Needs and Resources Over the Next Decade: State and Local Governments, in Public Finances, op. cit. supra note 13 , at 30,38 .
} 
estimate brought forth a chorus of objections, Kurnow has, in an even more recent paper, presented us with the results of a cross-sectional analysis which tend to support Netzer. Kurnow points out that the wide differences in estimates between Groves and Kahn, on the one hand, and Netzer and Kurnow, on othe other, are due largely to the fact that the latter investigators utilize market value to obtain elasticity coefficients while the former use assessed value. The Groves-Kahn estimate reflects actual relative change in tax yields with changes in income rather than the potential relative change as measured by Netzer and Kurnow. ${ }^{90}$

As assessment techniques and practices improve and the property tax rolls reflect more closely real market values, it would appear that the Netzer and Kurnow estimates would be the most relevant. Where such cases prevail, we can conclude that the tax is not insensitive to fluctuations in economic activity. We should note, however, that even if the income elasticity of the property tax is unity, this source of revenue cannot fulfill projected revenue requirements, for the income elasticity of local government expenditures is in excess of two.

There are also negative factors working against the strengthening of the property levy. Vast amounts of property are being removed from the tax rolls as freeways, expressways, and public parking facilities are constructed. ${ }^{01}$ There is also a long-time lag in the urban renewal program. Large stretches of urban land are now vacant, either cleared or with varying amounts of rubble awaiting removal.

Property taxes are deductible from federal income tax liabilities. This factor reduces the net burden on individuals who pay federal income taxes and itemize their deductions. Corporations also have this advantage. Counterbalancing this salutary effect on local governmental finances, however, is the fact that under the doctrine of instrumentalities, local jurisdictions do not tax federal property. Moreover, the Department of Defense, the Atomic Energy Commission, and other federal agencies often take title to property acquired but used or held by private contractors working under the direction of federal agencies. In addition, federal property sold to private individuals is often withheld from local property tax rolls until payments for the property are completed. These continuing cases along with the basic stock of federal governmental property represent a significant part of total property in the United States. The current market value of federal property is not known, although the accumulated historical cost of federal property has been estimated in excess of $\$ 200$ billion in $195^{8.92}$

In addition to the immunity of federal property, local governments must also contend with the tax exempt properties of religious, educational, and nonprofit organizations as well as state governments. While we do not know the market

${ }^{90}$ Kurnow, On the Elasticity of the Real Property Tax, 88 J. Finsnce 56-58 (xg63).

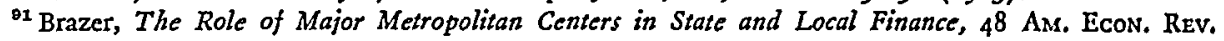
308 (1958).

${ }^{92}$ Ecker-Racz \& Labovitz, Practical Solutions to Financial Problems Created by the Multilevel Political Structure, in Public Finances, op. cit. supra note 13, at 139-41. 
value of all this property, it seems clear that the financial affairs of local governments are significantly affected by the many exclusions of property from the tax rolls.

Another factor that may prove to have a negative effect on property tax yields in the core cities is the changing relative income levels of its residents. Demographic and economic changes may bring falling relative income levels which could be a causal factor in the decline in the value of residential property on a per capita basis. ${ }^{03}$

Table Three indicates that nonproperty taxes have been increasing in importance relative to property taxes. ${ }^{94}$ This fact has been discernible since the 1920 , but it has only been since World War II that the absolute amount of nonproperty taxes has grown to be a significant part of total tax revenues. Nonproperty taxes increased from three to twelve per cent of total tax revenues between 1927 and 1962 , but the most rapid rate of growth occurred between 1945 and $195^{\circ}$.

The ratio of local nonproperty taxes to total local taxes varies widely among the states. In 1962 this ratio ranged from .5 per cent in Indiana to 44.2 per cent in Alabama. The ratio in the District of Columbia was sixty-three per cent. The ratio was less than five per cent in seventeen states, between five and ten per cent in thirteen states, between ten and fifteen per cent in six states, between fifteen and twenty per cent in four states, and over twenty per cent in eleven states. Except for the New England states, most of the highly urbanized states have a ratio of ten per cent or higher. There is a relatively high positive rank correlation between city size and the ratio of nonproperty taxes to total city taxes collected. The cities of Philadelphia, Washington, St. Louis, New Orleans, Kansas City, Columbus, Louisville, and Toledo each collected over half of their tax receipts from nonproperty levies in 1962. In the same year New York, Chicago, and Los Angeles each received over thirty-five per cent of their total taxes from nonproperty tax sources. ${ }^{95}$

Several reasons have been advanced to explain the increased use of nonproperty taxes. They are: (I) the desire to find alternatives to the property tax when it is shared by overlapping jurisdictions, (2) tax diversification for its own sake, (3) tax equity, (4) the alleged deleterious effects on the location of business as result of increased property tax ratio, and (5) dissatisfaction with the administration of the property tax. ${ }^{96}$

The major nonproperty levies are sales, income, and license taxes. The most important is the sales tax. This source of revenue accounted for 57.8 per cent of nonproperty tax receipts in I962. New York City and New Orleans adopted general retail sales taxes before World War II, but it was not until 1945, when cities in California started to use this levy, that the revolution in local retail sales taxation

${ }^{\circ}$ Brazer, supra note 91, at 309.

" For a general view of local nonproperty taxes, see Doherty, Greater Use of Nonproperty Tax Sources, and McBride, State-Administered Local Taxes, Shared Taxes, and Grants in Aid, both in Proceedings of the National Tax Association 106-128 (I958).

${ }^{05}$ Advisori Commission on Intergovernmental Relations, Tax Overlapping in the United Strites 1964, at 49-50 (1964).

${ }^{\circ 0}$ Id. at 42 . 
really began. Within a decade almost 200 California municipalities had general sales tax ordinances. ${ }^{97}$ By 1962 approximately 2,000 local governments in twelve states imposed general retail sales taxes. Most of these governments were municipalities located in Illinois, California, and Mississippi. ${ }^{98}$

Cities in Alaska, New York, and Virginia levy general sales taxes even though their states do not use this source of revenue. These cities levy and administer their own taxes. Municipalities in four other states levy and administer their own taxes despite the fact that their states also have sales tax collection and other administrative facilities. In Illinois, California, Mississippi, New Mexico, and Utah local sales taxes are added to the state tax and the state collects and remits revenue to the local governments. ${ }^{99}$ Normally the state and local tax bases are identical. In Illinois and California, which contain approximately seventy-five per cent of all local sales taxing jurisdictions in the United States, county areas also employ the sales tax. ${ }^{\mathbf{1 0 0}}$ There is, therefore, no incentive for buyers to avoid the tax by shopping outside of municipalities.

Urban governments also employ a variety of excise or selective sales taxes. The most remunerative of these is the levy on public utility services. Local taxes on alcoholic beverages, tobacco products, and motor fuel are being adopted by an increasing number of communities. ${ }^{101}$

There are several alleged advantages of sales taxation. Thomas Hobbes, J. S. Mill, Alfred Marshall, Irving Fisher, A. C. Pigou, and Luigi Einaudi all favored the levy because it taxes an individual in accordance to what he removes rather than what he contributes to net national product. ${ }^{102}$ On a less philosophical level, the advantages are: ( $\mathrm{r}$ ) revenue productivity, (2) relative ease of administration, (3) relatively low cost of administration, and the fact that (4) it can be used to extract revenue from certain municipal residents and nonresident individuals who use city services but who would not otherwise contribute revenue, and (5) that it is a stable source of revenue. Bits of evidence and a priori reasoning tend to affirm the first four points, ${ }^{103}$ but the data negate the hypothesis that the tax provides a stable source of revenue. ${ }^{104}$

${ }^{\circ 7}$ Davies, First Decade of Municipal Sales Taxation in California, I8 AM. J. Economics AND SOCIOLOGY 49-54 (I958).

os Adyisory Commission on Intergovernmental Relations, State Constitutional and Statutory Restrictions on Local Taxing Powers 75 (I962); Advisory Commission on Intergovernmental Relations, Locat Nonproperty Taxes and the Coordinating Role of the State 34 (1961).

${ }^{\circ}$ Advisory Commission on Intergovernmental Relations, Tax Overlapping in the United STATES, op. cit. supra note 95 , at 47.

${ }^{100}$ Advisory Commission on Intergovernmental Relations, Local Nonproperty Taxes and the Coordinating Role of the State 34 (rg6r).

${ }^{201}$ Id. at 33-36; and Advisory Commission on Intergovernmental Relations, State Constitutional and Statutory Restrictions on Local Taxing Powers 78 (1962).

${ }^{202}$ See Nichotas Kaldor, AN Expenditure Tax II (1955); Irving Fisher \& Herbert W. Fisher, Constructive Income Taxation 24-27 (1942).

${ }^{103}$ Davies, Use of Local Retail Sales Taxes, 32 Western CrTy 34-35 (1956).

${ }^{104}$ Davies, The Sensitivity of Consumption Taxes to Fluctuations in Income, I5 Nar. Tax J. 28x-90 (1962). 
Since 1946 local sales tax revenues have increased by over 700 per cent which is a larger increase than any other source of revenue. The ratio of sales levies to total nonproperty taxes grew from 43.6 to 57.8 per cent between I946 and r963. Although the ratio of sales tax revenues to total tax revenues was only seven per cent in 1963 , it was but four per cent in $1946 .^{105}$

There is a good positive correlation between per capita sales tax revenues and city size. Per capita sales tax receipts ranged from $\$ 2.44$ in cities of less than 50,000 population to $\$ 36.38$ per capita in municipalities with over a million inhabitants. The percentage of our largest cities employing the tax is greater than for any other city size classification. It is interesting to note that per capita property tax receipts in cities with over one million residents is $\$ 94.94$ in 1963 .

Total municipal sales tax collections were $\$ \mathrm{I} .4$ billion in $\mathrm{Ig}_{3}$. These collections amounted to approximately 23.3 per cent of municipal property taxes and 16.9 per cent of total city taxes. ${ }^{100}$ The data tend to support the hypothesis that local sales taxes are primarily a municipal phenomenon, and the experience of the last two decades seems to indicate that municipal sales taxes will continue to grow in relative importance as well as absolute size.

Municipal income taxes represent I2.I per cent of all nonproperty taxes. Philadelphia adopted an income tax in 1939, but like the sales tax, it was not until after the war that broad permissive legislation permitted widespread use of the income levy. Pennsylvania's famous "tax anything" law permitted cities, boroughs, townships, and school districts to use this source of revenue. ${ }^{107}$ By 1960 over I, Ioo Pennsylvania taxing districts used the levy. In Ohio over sixty cities and villages had adopted municipal income tax ordinances by $1962 .{ }^{108}$ Cities in Kentucky, Missouri, Alabama, ${ }^{109}$ and Michigan also use the tax. Detroit is the most recent large city to adopt the levy. ${ }^{110}$

Most municipal income taxes are levied only on so-called "earned income." Rent, dividends, interest, and capital gains are commonly excluded from the tax base. The rates of taxation are constant, usually at one per cent, regardless of the level of income. ${ }^{111}$ Most ordinances allow no personal exemptions or deductions. ${ }^{112}$ In effect, most local income levies are flat rate taxes on gross wages.

${ }^{100}$ U.S. Buread of the Census, Governarent Finances in I963, at 22 (I964); Advisory Commission on Intergovernmental Relations, Tax Overlapping in the United States, I964, at 22 (1964).

100 U.S. Bureau of the Census, Compendum of City Government Finances in i963, at 6-7 (i964).

${ }^{107}$ The ADVISORY CoMmission on INTERgovernmental Relations, TAX Overlapping in the UNITED STATES, I964, at $45\left(\mathrm{Ig6}_{4}\right)$.

${ }^{209}$ Advisory Commission on Intergovernmentaz Relations, State Constitutional and Statutory Restrictions on locat. Taxing Powers 88 (I962).

${ }^{100}$ Ecker-Racz \& Labovitz, Practical Solutions to Financial Problems Created by the Multilevel Political Structure, in Public Finances, op. cit. supra note 13, at 144.

${ }^{120}$ Advisory Commission on Intergovernmental Relations, State Constitutional and Statutory Restrictions on Local, Taxing Powers 89 (1962).

${ }^{112}$ The fact that the tax rate is constant does not necessarily mean that the municipal income levy is a proportional tax.

${ }^{112}$ Taylor, Local Income Taxes After Twenty-One Years, I5 NaT. TAx J. I13, I15 (I962). 
One of the main arguments advanced in favor of the tax is its revenue productivity. On the basis of the few studies made, the evidence tends to support the revenue productivity hypothesis. ${ }^{113}$ Another alleged advantage is the ability it gives the core city to tax nonresidents who work in the central city and use its services. A questionable corollary of this alleged advantage is the provision of an economic incentive for suburbs to incorporate with the core city. The cost of administering municipal income taxes is relatively low, ranging between two and five per cent of total revenue collected. Withholding taxes at the source accounts for between seventy and eighty per cent of total income tax collections. This factor helps to keep governmental costs of collection low. ${ }^{114}$

The municipal income tax is not without disadvantages. The fact that the geographical boundaries of local taxing jurisdictions (or any taxing jurisdiction) are not coterminous with economic activity raises serious problems with the relatively few cities that tax corporate incomes. Multiple outlet firms with intra- and interstate facilities create income over broad geographical areas. The question of where the income is earned and, therefore, how much is taxable in the taxing city is almost unanswerable. ${ }^{115}$ The use of allocation formulae has not been conspicuously successful at the state level of administration.

Another disadvantage of the income tax arises because of the balkanization of local governments within a metropolitan area. If both the central city and the suburb adopt income tax ordinances, the suburbanite who works in the central city may be subject to double taxation of his income. Where there are reciprocal agreements between jurisdictions, the worker normally pays the tax to the government of his residence and receives a tax credit in the jurisdiction where he earns income. Reciprocal agreements usually prevent the central city from taxing daytime residents who live in suburbs. ${ }^{116}$

Another disadvantage of the tax is its alleged effect of driving large taxpayers out of the taxing jurisdiction. There is no strong evidence one way or the other on this hypothesis. It should be noted that the data available seem to indicate that municipal taxes appear to be more substitutable than complementary to other taxes. If this is true, it is doubtful that one would observe any significant emigration from taxing municipalities.

Although officials in Atlanta, Baltimore, Boston, Chicago, Dallas, Fort Worth, Minneapolis, New York, and San Francisco have seriously considered local income taxes, ${ }^{117}$ it does not appear that this source of revenue will grow in importance in the near future. Local income taxes produced $\$ 308$ million in 1962 . Income tax

${ }^{118} 1 d$. at $\mathrm{II} 6-\mathrm{x} 8$.

124 $l d$. at $118-23$.

${ }^{115}$ Brazer, The Role of Major Metropolitan Centers in State and Local Finance, 48 AM. Econ. REv. 309-II (I958).

${ }_{110}$ Buehler, Revenue Improvements Under Present Laws and Government Structure, in Financino Metropolitan Governiment 209-10 (1955).

${ }_{117}$ Taylor, supra note II2, at II4. 
collections increased by over fourteen times between 1942 and 1962 , but in each biennium over these two decades income tax revenues remained at only one per cent of total local tax revenues. ${ }^{118}$

Taxes other than property, income, and sales levies accounted for 2.2 per cent of total local revenue in 1963 . They increased by 335 per cent between I946 and I963 and were responsible for about $30 . \mathrm{I}$ per cent of all nonproperty tax revenue in 1962.

The most important part of this category, called "other taxes" by the Census Bureau, is the license tax. In $\mathrm{I} 6_{3} 3$ license levies on motor vehicles, building equipment permits, and other business operations represented five per cent of total taxes and I 4.6 per cent of nonproperty taxes in the largest forty-three cities in the United States. The entire category "other taxes" comprised only 16.9 per cent of nonproperty revenues for the forty-three cities. ${ }^{119}$ This source of revenue is a much less important nonproperty revenue producer in these forty-three cities with populations of 300,000 or more than other smaller local governments. Conversely, sales and income taxes are much more important to these large urban centers.

Although localities in all fifty states use "other taxes, ${ }^{120}$ it does not appear that they will grow significantly in importance in the near future. While they increased from approximately $\$ 200$ million to $\$ 888$ million between 1946 and Ig63, they produced four per cent of total tax revenue in both 1946 and $1963 .{ }^{121}$

Despite the fact that local governments in some states have achieved a measure of fiscal independence under home rule provisions, certain statutory, constitutional, and charter provisions have severely restricted the use of nonproperty taxes. These restrictions vary from outright prohibition to specifications with respect to type of locality, extent of the tax base, and the maximum rates allowable. ${ }^{122}$ Even so, most students of local public finance seem to be quite bullish concerning the future prospects of local nonproperty taxes. The author of a recent study predicted that the ratio of nonproperty to total local tax revenue will increase to twenty-five per cent by 1970, but as Thompson notes, this seems to be a particularly sanguine view in light of the fact that there was no appreciable change in this ratio during the I950 decade. ${ }^{123}$

A survey of local taxes should include mention of the equity effects of taxes, but this is still an open question. The weight of the partial evidence we do have indicates

\footnotetext{
${ }^{118}$ Advisory Commission on Intergovernmental Relations, Tax Overlapping in the United STATES I 964 , at $43(1964)$.

${ }^{120}$ U.S. Bureau of the Census, Compendium of City Government Finances in I963, at 78-93 (1964).

${ }^{120}$ Advisory Commission on Intergovernmental Relations, State Constitutional and StatutoRy Restrictions on LOCAL TAXiNg Powers 76-77 (I962).

121 The Adisory Commission on Intergovernmental Relations, Tax Overlapping in the United StATES I964, at 43 (I964).

192 The Advisory Commission on Intergovernmental Relations, State Constitutional and Statutory Restrictions on Local Taxing Powers 79-82 (I962).

${ }^{193}$ See Wilmur R. Thompson, A Preface to Urban Economics 245 (1963).
} 
that the whole structure of state-local taxes is mildly regressive in nature. ${ }^{124}$ Among other factors this conclusion is based on the acceptance of the criterion that annual earned income is the "proper" standard upon which to adjudge the regressivity, proportionality, or progressivity of a tax. Other criteria, however, have been shown to be equally defensible. ${ }^{125}$

Even where there is agreement on the appropriate criterion, there is no agreement on whether the property tax is regressive or proportional. ${ }^{128}$ Moreover, there is no agreement on whether the sales tax is regressive, proportional, or progressive. ${ }^{127}$ The fragmented evidence on municipal income taxes is also inconclusive. Taylor has argued that local income taxes are proportional. ${ }^{128}$ Musgrave's empirical study shows that state-local income taxes are mildly progressive, ${ }^{120}$ while G. A. Bishop's statistical analysis reveals that state and local income taxes manifest both regressivity and progressivity depending on the income classes compared. ${ }^{130}$

Equity questions are no doubt important. Indeed, Galbraith may be correct when he states that due to equity considerations the modern liberal has been the effective enemy of better education, sewer systems, parks, and recreational facilities. ${ }^{131}$

All empirical studies of the equity impact of taxes are, however, based on hypotheses which are behavioral in nature, but largely untested. This state of affairs will continue for some time because a quantitative measurement of the incidence of a tax will require, among other things, an econometric analysis of literally millions of supply and demand functions.

Fee, service, or user charges are a second general source of revenue for urban governments. They are defined as "amounts received from the public for the per-

${ }^{124}$ Cf. HANSEN \& Perroff, op. cit. supra note 87, at 35; Musgrave, The Incidence of the Tax structure and Its Effects on Consumption, Staff of Subcomm. on Tax Policy of the Joint Economic Comm., 84th Cong., ist Sess., Federal Tax Policy for Economic Growth and Stability (Papers Summitted by Panelists Appenring Before the Subcomm. on Tax Policy 96 f. (Comm. Print 1955) [hercinafter cited as Federal Tax Policy for Economic Growty and Stability]; Bishop, The Tax Burden by Income Class, 14 NaT. TAX J. 54 (196r).

${ }^{136}$ See Davies, Commodity Taxation and Equity, I6 J. of Finance 581-90 (I961), and note 102 supra.

${ }^{120}$ Cf. Bishop, supta note 124, at 54: Harold Groves, Financing Government 64-65 (1964); John F. Due, Government Finance 368-69 (I963); James N. Morgan and Others, Income and Weltare in THE UNITEd States C. I9 (1962); and Musgrave, The Incidence of the Tax Structure and lis Effects on Consumption, in Federal TAX POLICY For Economic Growth and Stamility, op. cit. supra note 124, at $98 \mathrm{ff}$.

${ }^{127}$ Cf. Bishop, supra note 124, at 54; Musgrave, supra note 124 , at 98 f.; Miller, Sales-Tax Progressivity Attributable to a Food Exemption, 4 NAT. TAx J. 148-50 (I95I); Hansen \& PERLopp, op. cit. supra note 87, at 35-37; Henle, Effect of Taxation on Workers, in Federal. TAx Policy for Economic Growith and Stability, op. cit. supra note I24, at 90. AFL-CIO, STATE and Local. TAXes 77 (1958). For both nonparametric and parametric approaches to this sales tax problem, sce Davies, An Empirical Test of Sales-Tax Regressivity, 67 J. Poz. Econ. 72-78 (1959); Davies, The Relative Burden of Sales Taxation, 19 AM. J. Economics and Socrology 29I-96 (1960); Davies, Progressiveness of a Sales Tax in Relation to Various Income Bases, 50 AM. Econ. Rev. 987-95 (r960).

${ }^{128}$ Taylor, supra note $\mathrm{rr2}$, at $\mathrm{r24}$.

${ }^{120}$ Musgrave, The Incidence of the Tax Structure and Its Effects on Consumption, in Federal Tax Policy FOR ECONOMIC GROWTH AND STABILITY, op. cit. supra note 124, at $98 \mathrm{ff}$.

${ }^{180}$ Bishop, supra note 124 , at 54 .

${ }^{131}$ John Kenneth Galbraith, The Affluent Society 315-16 (1958). 
formance of specific services benefiting the person charged and from sales of commodities."132 Contrasted with taxes, fees are voluntary rather than compulsory contributions to government.

Service charges are utilized by municipalities in association with providing a wide variety of goods and services. A partial list includes: education, health and hospitals, housing, sanitation, nonhighway transportation, highways, parks and recreation, libraries, police, and fire protection. ${ }^{133}$ If all local governments are considered (including school districts), education ranks first as the producer of revenues from fees. It accounts for twenty-six per cent of all user charges. ${ }^{134}$ In our forty-three largest cities, however, over thirty per cent of the total revenue collected from fees. in 1963 was due to housing-urban renewal and sewerage charges. ${ }^{135}$

The most common methods of determining the magnitude of a fee or price are cost of service and the "welfare principle." Under the first method the price is set on the basis of either the average or marginal cost of producing the service. ${ }^{136}$ Given the following conditions: (I) that the current distribution of income is regarded as acceptable, (2) that the marginal cost of producing the good or service includes marginal social costs, (3) that the independence hypothesis holds, and (4) that prices are roughly equal to marginal costs in the other sectors of the economy, then fees should be set on the basis of marginal costs in order to achieve an optimum allocation of resources. ${ }^{137}$

The so-called "welfare" criterion of pricing bases the price on ability to pay which usually means the level of an individual's current earned income. The lower a person's income, the lower the price. There is, then, a direct positive correlation between the price charged and the level of a person's income. ${ }^{138}$ There is an element of subsidization under "welfare" pricing. ${ }^{139}$

In a study of fees in Los Angeles, Stockfish revealed that due to underpricing there were significant amounts of "subsidy in kind" to certain area residents. He claims that by setting an appropriate set of prices, the city of Los Angeles could have raised enough additional money to finance over forty per cent of its annual expenditures. ${ }^{110}$

The case for using fees is strong if: (I) there would be significant waste if the good or service has a zero price, (2) the utility flowing from the good or service

138 U.S. Bureav of the Census, Compendum of City Government Finance in ig63, at 96 $\left(x_{9} 6_{4}\right)$.

${ }_{103}$ National Industrial Conference Board, Use of Service Charges in Local Government 20-2I (1960).

134 U.S. Bureau of the Census, Governmental Finances in I963, at 22 (Ig64).

${ }^{135}$ U.S. Bureau of the Census, Compendum of City Government Finances in 1963, at 78 (I964).

130 National Industrial CONFerence BoArd, op. cit. supra note 133 , at $4 \mathrm{I}$.

${ }^{137}$ See DuE, op. cit. supra note 126, at 397-98.

${ }^{138}$ National Industrial CONFerence Board, op. cit. supra note 133, at $4 \mathrm{~T}$.

${ }^{230}$ Leland, An Ideal Theoretical Plan of Finance for a Metropolitan Area, THE TAX Institute, Finsncing Metropolitan Governasent 258 (1955).

${ }^{160}$ Stockfish, Fee and Service Charges As a Source of City Revenues: A Case Study of Los Angeles, I3 Nat. TAx J. 97-99 (1960). 
accrues primarily to the individual purchaser, and (3) the cost of collecting the user charge is not excessive. ${ }^{141}$ Fees provide a relatively certain source of revenue, can be altered to reflect changes in consumer demand, and the revenue is not restricted to certain projects. ${ }^{142}$

The appropriate area for market pricing in the governmental sector may be a relatively small one. ${ }^{143}$ Yet a very good case can be made for the use of certain service charges in the general area of governmental finance. ${ }^{144}$ Between 1946 and I963 local governmental fee revenues increased by approximately 588 per cent, second only to the sales tax as the most rapidly growing source of local revenue. In 1963 fees were I5.4 per cent of total revenues and over twenty-two per cent of total locally derived revenues. On the basis of its history during the most recent two decades, the prospects for market pricing in the urban public sector appears to be quite bright.

The third general source of revenue to urban governments is the grant in aid. There are two basic types of grants, conditional and block grants. The former are given for a particular purpose and are subject to supervision and control. All federal grants in the United States are of this nature. Block grants are general unallocated grants with no restrictions on the use of the money as long as it is used for a public purpose. $^{145}$

There are two basic ways to distribute conditional grants. One way is to allocate funds in accordance with a formula which only takes into consideration the "needs" and not the income or wealth of the receiving jurisdiction. An educational grant, for example, may be based only on the number of pupils in average daily attendance. ${ }^{146}$ The alternative basis for the distribution of conditional grants requires a matching contribution of some proportional amount from the receiving jurisdiction. The proportions can vary depending on the purposes and wishes of the granting government. ${ }^{147}$

Grants to local governments increased by almost 500 per cent between 1946 and I963. They constituted $\$ 12.7$ billion or almost thirty-one per cent of total local receipts in 1963 . The great bulk of grant funds to municipalities come directly from state governments. Federal grants given directly to local governments (mostly urban governments) amounted to only $\$ 890$ million in 1963 , but the increase between I962 and I963 was approximately thirty per cent. Recent political developments indicate that direct federal grants to urban governments will continue to increase rapidly.

${ }^{141}$ DuE, op. cit. supra note 126, at 396-97.

${ }^{142}$ National Industrial Conference Bonrd, op. cit. supro note $x 33$, at 12.

${ }^{143}$ Browalee, User Prices vs. Taxes, in Public Finances, Needs, Sources, and Utilization 42t (196r).

${ }_{144}$ Robinson, Benefits Received Financing in the Federal System, 27 NAT. TAx J. $24 \mathrm{I}-52$ (1964).

${ }^{145}$ Due, op. cit. supra note 126 , at 447 .

${ }^{140}$ Ibid.

${ }^{147}$ Hirsch, Urban Government Services and Their Financing, in WERNER Z. Hirsch (ED.), UndAN LiFE AND Form 142, at $152-53$ ( 1963 ). 
Data based on a study of the 1957 Census of Governments show that the share of metropolitan area expenditures financed by intergovernmental aids vary widely among the municipalities. Grants on a per capita basis varied from $\$ 15$ to $\$ 70$ per person in urban governments. Welfare grants contribute significantly to this wide variation. Grants per capita do not correlate with the level of local expenditures. ${ }^{148}$

This same study revealed that fifty-six per cent of federal and state aid was distributed to the SMSAs. The SMSAs contained approximately seventy per cent of our population at that time. ${ }^{149}$ The data underlying table one in this paper indicate that the fifty-six per cent figure for 1957 has now increased to approximately sixty-two per cent. In 1957 approximately fifty-five per cent of state grants and seventy-three per cent of direct federal grants to local governments went to the metropolitan areas. These figures were sixty-one and seventy-five per cent, respectively, in I962. ${ }^{150}$ All of the recent available evidence indicates that both state and direct federal grants to urban governments will increase significantly during the next several years.

\section{Concluston}

Although it is beyond the scope of this paper, it seems proper to mention that many alternative plans have been advanced to cope with the financial problems existing in metropolitan governments. These range from the increased use of contractual agreements among governments to the institution of federal corporations for metropolitan areas, ${ }^{151}$ from annexation and consolidation to the use of extraterritorial powers, from voluntary metropolitan councils to the urban county, and from city-county separation to city-county consolidation. ${ }^{152}$

All of these plans seem to have merit, yet it is clear that we are painfully ignorant when it comes to analyzing and explaining the urban scene. We lack fundamental knowledge. ${ }^{153}$ It may, in the face of the rapidly rising expectations of the urban population, seem trite and anachronistic to make a plea for more basic and applied research on metropolitan problems. ${ }^{154}$ But that is exactly what is required if rational, albeit temporary, solutions are to be found for urban problems.

${ }^{2 *}$ Mushkin, Intergovernmental Aspects of Local Expenditure Decisions, in Howard G. Schallen (Ed.), Public Expendtrure Decistons in the Urban Community 39-4I (i963).

${ }^{200}$ Id. at 43.

160 Ibid.

${ }^{161}$ Hirsch, Urban Government Services and Their Financing, in HiRsch (ED.), op. cit. supra note 147, at 164 .

103 Advisory Commission on Intergovernmental Relations, Alternative Approaches to Governmental Reorganization in Metropolttan Areas ig-80 (1962). See also Staff of House Comm. on Government Operations, 87th CoNg., ist Sess., Government in Metropoldtan Areas 7-9 (Comm. Print 196r).

${ }^{263}$ Sec Perloff, A National System of Metropolitan Information and Analysis, 52 AMc. Econ. REv. 356-64 (1962); Hirsch, Design and Use of Regional Accounts, id. 365-73; Cohen, Organization for Data Collection, Analysis, and Reporting, id. 374-80. See also Netzer, Data for the Public Finance Sub-Account, and Burkhead, Public Finance As an Integral Part of Regional Accounts, addresses delivered at the Conference on Regional Accounts, held on November 30, 1962, at Miami Beach, Fla.

${ }^{154}$ See Wood, The Contributions of Political Science to Urban Form, in Hirsch (ED.), op. cit. supra note 147 , at $122-26$. 